\title{
Distraksiyon osteogenezinde düşük yoğunlukta ultrason stimülasyonunun kemik mineral yoğunluğuna etkisinin DEXA ile incelemesi
}

\section{Evaluation of the effect of the lipus on bone mineral density from the distraction osteogenessis technique by use of DEXA}

Fatih Mehmet Coskunses, DDS, PhD, ${ }^{\mathrm{a}}$ Funda Tugcu, DDS, $\mathrm{PhD}^{\mathrm{b}}$

${ }^{\text {a }}$ Gumussuyu Military Hospital, Department of Oral and Maxillofacial Surgery, Beyoğlu, İstanbul.

${ }^{\mathrm{b}}$ Ankara University, Faculty of Dentistry, Department of Oral and Maxillofacial Surgery, Besevler, Ankara.

Received: 06 December 2011 Accepted: 18 January 2012

\section{ÖZET}

Amaç: Distraksiyon osteogenezi (DO), osteotomi ile oluşturulmuş kemik segmentlerinin apareyler yardımı ile kademeli olarak birbirinden ayrılmasıyla birlikte yeni kemik oluşumunun sağlandığı cerrahi bir yöntemdir. $\mathrm{Bu}$ çalışmada Düşük Yoğunlukta Ultrason Stimülasyonu'nun (DYUS) DO' inde oluşan kemiğin mineral yoğunluğu üzerine etkinliğinin, cerrahi öncesi ve cerrahi sonrası otuzuncu ve altmışıncı günlerde Dual Enerji X Işını Absorbsiyormetrisi (DEXA) yöntemi ile fotodensitometrik olarak değerlendirilmesi amaçlanmıştır.

Gereç ve Yöntem: Çalışmada 8 Yeni Zelanda tavşanı dahil edilmiştir. Tavşanların mandibulalarına DO uygulaması yapılmıştır. 4 tavşana DO uygulamasına ek olarak distraksiyon periyodunda DYUS uygulaması yapılırken 4 tavşana sadece DO uygulaması yapılarak kontrol grubunu oluşturmaları sağlanmıştır.

Bulgular: DYUS uygulaması yapılan grupta kemik mineral yoğunluğunun otuzunca günde başlangıç seviyesinin üzerinde bir değere ulaştı̆̆ gözlenmiştir. Aynı grupta altmışıncı günde kemik mineral yoğunluğu değerleri bir miktar daha artmıştır. Kontrol grubunda otuzuncu günde kemik mineral yoğunluğu azalırken altmışıncı günde başlangıç seviyesine yakın değerlere ulaşılmıştır.

Sonuç: DYUS' un etkisiyle DO'inde kemik olgunlaşmasının büyük bir bölümünün ilk 30 günde tamamlandığı ve kazanılan kemiğin fonksiyonel kuvvetlere direnç gösterebileceği düşünülebilir.

Anahtar Kelimeler: Distraksiyon Osteogenezi, düşük yoğunlukta ultrason stimülasyonu, kemik mineral yoğunluğu.

\begin{abstract}
Objectives: Distraction osteogenesis (DO) is a surgical method which provides new bone formation by gradually increasing the distance between bone segment surfaces created by osteotomy. In the present study assessing the effect of low intensity pulsed ultrasound stimulation (LIPUS) on bone mineral density (BMD) of the bone formed in distraction osteogenesis (DO) with dual energy X-ray absorptiometry (DEXA) and making a comparison between postoperative 30th and 60th days was aimed.
\end{abstract}

Materials and Methods: A total of $8 \mathrm{New}$ Zealand rabbits were used in the study While DO was applied to 4 rabbits, 4 were applied $30 \mathrm{~mW} / \mathrm{cm} 2$ (1Mhz) LIPUS on DO site for $20 \mathrm{~min}$ a day during distraction period in addition to DO application

Results: In LIPUS group, mean BMD values were seen to be above the initial values on 30th day while on 60th day the increase ratio was greater when compared. BMD values were seen to be below initial values both on 30 and 60 days postoperatively in control group.

Conclusion: By the effect of LIPUS, majority of bone maturation is completed within the first 30 days and gained bone may resist to functional forces.

Key Words: Distraction osteogenesis, low intensity pulsed ultrasound stimulation, bone mineral density.
Fatih Mehmet COSKUNSES

Gumussuyu Military Hospital,

Department of Oral and Maxillofacial Surgery,
Beyoğlu, İstanbul.

Phone: 905058408892 / Fax:+90 2122518500

e-mail: fcoskunses@gmail.com 


\section{GíRiş}

Distraksiyon osteogenezi (DO) kemik defektlerinin onarımı amaciyla uygulanan tedavi yöntemlerinden biridir. DO, osteotomi ile oluşturulan kemik segmentlerinin kademeli olarak birbirlerinden uzaklaştırılarak yeni kemik oluşumunun sağlandığı biyolojik olaydır. Distraksiyon osteogenezinde karşılıklı kemik segmentleri arasında oluşan kallusa belirli bir ritim ve hizda gerilim kuvvetleri uygulanır ve yeni doku oluşumu stimule edilir. Distraksiyonla birlikte dokuya gelen kan miktarında artış ile gerilimin stimulatör etkisi metabolik aktivitede artış sağlar. ${ }^{1}$ Kemiğe verilen distraksiyon kuvvetleri aynı zamanda, çevre yumuşak dokularda da bir gerilim yaratarak, "distraksiyon histogenezisi" olarak isimlendirilen adaptif değişiklikler zincirini başlatır. Aşamalı traksiyon kuvvetleri ile meydana getirilen gerilim streslerinin etkisi altında fonksiyonel yumuşak doku matriksinde, periferal sinirler, kas, cilt, periodontal ligament, kan damarları, sinir paketleri ve diş etini içeren komşu dokularda da aktif histogenezis oluşmaktadır. $^{2}$

İlk DO uygulaması 1905 yılında Codivilla tarafindan femurun aksiyal cekim kuvvetlerine bağlı olarak uzatılmasıyla literatürde yerini almıştır. $\mathrm{Bu}$ çalışmada deformiteye bağlı femur kısalığının, oblik osteotomi sonrası aksiyel çekim kuvvetleri ile uzatılması sağlanmıştır. ${ }^{3}$ Modern DO ise, 1950'li y1llardan itibaren Rus ortopedist Gabriel Ilizarov'un çalışmalarından köken almış olup günümüze kadar gelişimini sürdürmüştür. Canlı dokular üzerinde kademeli esnetmenin yaratacağ 1 gerilimin bu dokularda rejenerasyon ve aktif büyümeyi uyardığını belirten araştırmacı bu prensibi 'gerilim-stress' kanunu olarak isimlendirmiştir. ${ }^{1,3}$ Çene yüz bölgesinde DO ilk defa 1973 yılında Synder ve arkadaşları tarafından köpeklere alt çene uzatılması amaciyla kullanılmıştır. ${ }^{4}$ McCarthy ve ark. ${ }^{5}$ mikrognati nedeniyle alt çenede angulus bölgesine ağı diş1 distraktör uygulaması ile 4 hastada 18-24 mm kemik kazanımı sağlamışlardır.

Kemik dokunun onarımının uyarılarak iyileştirilmesi amacıyla farklı cerrahi ve cerrahi olmayan stratejiler keşfedilmiştir. Cerrahi olarak kemik defektlerinin iyileşmesinde kemik greftlerinin kullanımı yaygin olarak uygulanmaktadır. Cerrahi olmayan yöntemler arasinda elektrik ve elektromanyetik alanların oluşturulması geçmişte ve günümüzde kullanılmaktadır. ${ }^{6}$

Ultrason stimülasyonu mikro mekanik titreşimlerin kemik ve kemik hücreleri üzerine uygulanarak iyileşmenin hızlandırılmasını amaçlar. Ultrason dalgaları uzunlamasına yayılan dalgalardır. Ultrason dalgalarını üretmek amaciyla piezoelektrik kristaller içerindeki parçacıklar uyarılarak dalgalanma oluşturmaları sağlanır. 1 saniye içerinde oluşan titreşim sayısına frekans denir ve parçacıklar üzerine gelen her bir uyarı siklüsüne 1 Hertz denir. 1000 Hertz, 1 KiloHertz ile eşdeğerdir ki bu da 1 Kilohertz' in saniyede 1000 uyar1 siklusuna sahip olduğu anlamına gelir. Ultrasonun yoğunluğu ise santimetreye iletilen ortalama güç olarak ifade edilir $(\mathrm{mW} / \mathrm{cm} 2)$.

Ultrason stimülasyonu uygulamasinda kemik üzerine gelen titreşim dalgalarının fizyolojik stres gibi etki göstererek kemik iyileşmesini uyardığ düşünülmektedir. $^{7}$ Daha farklı şekilde anlatılmak istenirse ultrason stimülasyonunun, piezo-elektrik ve hücre zarı üzerinde anjiyogenetik (damarlanma) etkiden oluştuğu düşünülmektedir.

Kemik mineral yoğunluğu (KMY) ölçümü, kemik dokusunda santimetre başına düşen madde miktarının izlenmesini sağlayan bir ölçüm yöntemidir. KMY ölçümü kemiğin yük taşıma kapasitesinin ölçümüyle beraber kırık riski ve taşıma kapasitesini değerlendirir. KMY ile yük taşıma kapasitesi ve kemiğin kırık riski arasında istatistiksel bir ilişki vardır. KMY ölçümü minimal invaziv yöntemler yardımı ile ortaya koyduğu risk 
değerlendirmesi yönüyle yaygın olarak kullanılmaktadır.

Uzun y1llardır KMY'nun ölçümü amaciyla konvansiyel radyografiler kullanılmakla beraber son yıllarda gelişen teknoloji yardımıyla tek ve çift foton absorbsiyometrisi, kantitatif bilgisayarlı tomografi, kantitatif ultrason, radyogrametri, dijital X-1şını radyogrametrisi ile tek ve çift $\mathrm{X}-1$ şını absorbsiyometrisinin ölçüm yöntemlerinde kullanılması yaygınlaşmıştır.

Dual Enerji X-1şını Absorbsiyometri'si (DEXA), radyoizotop yerine $X$ işınlarının kullanıldığı iki farklı enerji düzeyindeki fotonların doku tarafindan farklı absorbsiyonları ile ölçüm yapan KMY ölçüm yöntemidir. Tüm DEXA cihazlarında X 1şını kaynağı ve $X$ 1şını dedektörü bulunur. Ölçüm yapılacak olan dokuya $40 \mathrm{kV}$ ile $140 \mathrm{kV}$ aralığında iki farklı enerji seviyesinde $\mathrm{X}$ 1şını demeti gönderilerek gr/cm2 olarak KMY sonuçları verilir.

Çalışmamızda deneysel olarak DO uygulaması sırasında distraksiyon sahasına Düşük Yoğunlukta Ultrason Stimülasyonu (DYUS) uygulayarak DYUS'un, DO'nin farklı safhalarındaki kemik iyileşmesi ve kemik mineral yoğunluğu üzerine olan etkisi ile DYUS uygulanan ve uygulanmayan DO sahalarında DEXA

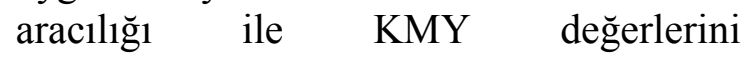
karşılaştırılması amaçlanmıştır.

\section{GEREÇ VE YÖNTEM}

Çalışma için Ankara Üniversitesi Hayvan Deneyleri Yerel Etik Kurulundan 30/01/2008 gün ve 2008-18-71 no'lu kararı uyarınca gerekli onay alınmıştır. Çalışma 3-4 aylik, 8 adet erkek Yeni Zelanda tavşanı üzerinde planlanmıştır. Genel anestezi altında yapılan tüm müdahaleler insani yöntemlere uygun olarak tavşanların 4 tanesine DO uygulanırken diğer 4 tanesine ise DO uygulamasina ek olarak DO sahasina distraksiyon periyodu süresince günde 20 dakika boyunca $30 \mathrm{~mW} / \mathrm{cm} 2$ (1Mhz) DYUS uygulamas1 yapılmıştır. Operasyonların başlangıcında, operasyon sonrası 30 ve 60 'ınc1 günlerde opere edilen sahaların, DEXA incelemesi yapılmış ve kontrol amaçlı standart radyografileri alınmıştır.

Cerrahi Yöntem: Steril şartlar altında deney hayvanının sol mandibula bölgesi tüylerden temizlenerek ve yüzey antiseptikleri kullanılarak operasyona hazır hale getirilmiştir. 10-20 mg/kg Ketamin ve $3 \mathrm{mg} / \mathrm{kg}$ Rompun ile genel anestezinin sağlanmasının ardından mandibula alt kenarının $0.5 \mathrm{~cm}$ altından ve alt kenara paralel olacak şekilde $2.5 \mathrm{~cm}$ uzunluğunda cilt insizyonu yapılmıştır Künt diseksiyon ile mandibula alt kenarına ulaşılmış ve periost alt kenar boyunca insize edilip mandibular kemiğge ulaşılmıştır. Mandibula korpusunun ramus mandibulaya $1 \mathrm{~cm}$ uzağından başlanacak şekilde rond frezler yardımı ile osteotomi hattı belirlenmiştir. İnce uçlu düz testere ve $25.000 / \mathrm{dk}$ devir hızla yoğun serum fizyolojik soğutması kullanılarak kesi hattı apikal ve koronal kenara $2 \mathrm{~mm}$ kalacak şekilde hazırlanmıştır. Osteotomi hattının her iki tarafına özel tasarlanmış distraktörün plakları uyumlandırılarak tespit edilmiş ve osteotomi tamamlanmıştır (Şekil 1). DO sonrasında tüm tavşanların sol mandibulalarında ortalama $10 \mathrm{~mm}$ kemik kazanımı sağlanış ve buna bağlı olarak tüm tavşanlarda çapraz kapanış oluşmuştur (Şekil 2).

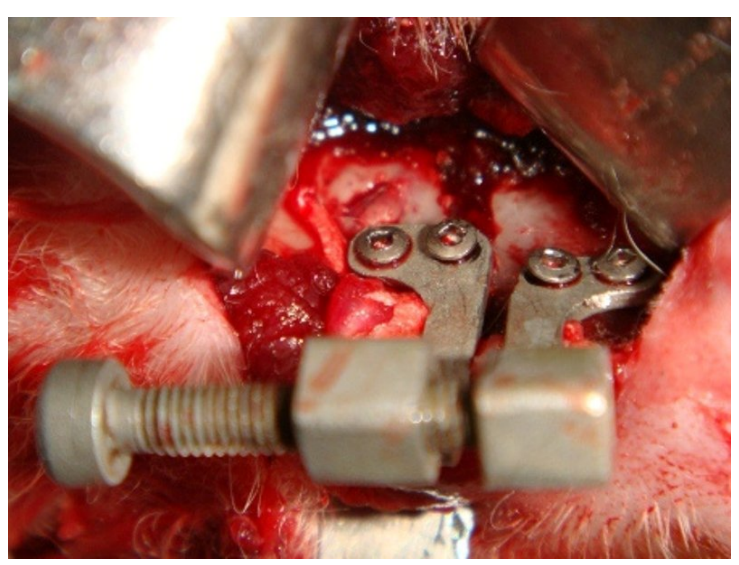

Resim 1. Mandibulaya yerleştirilen distraktör. 


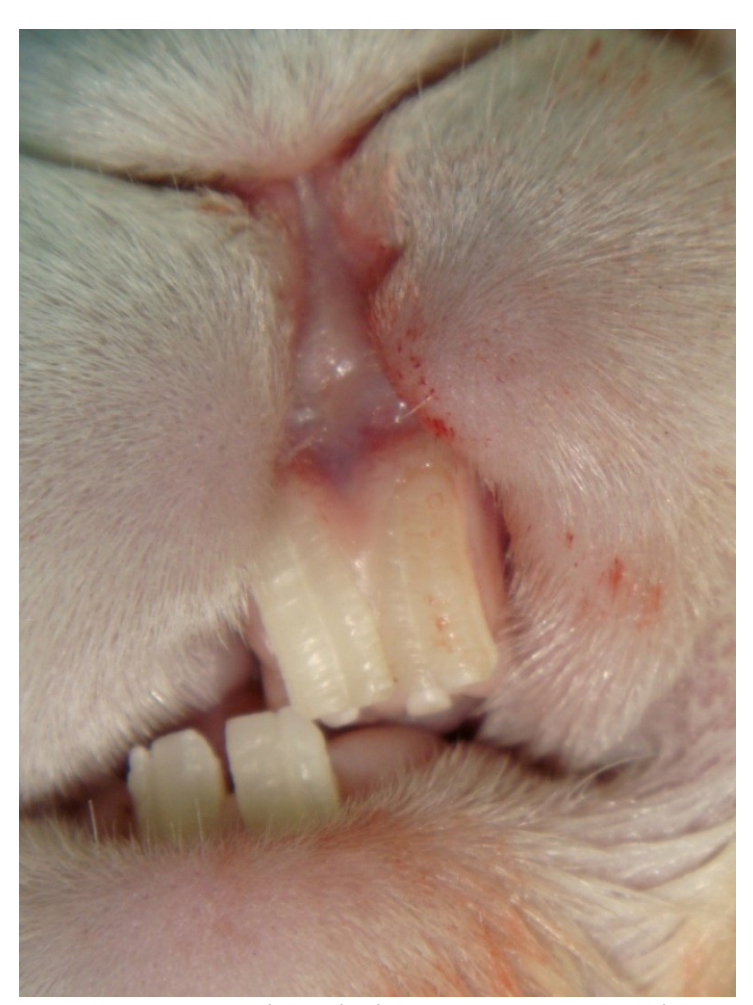

Resim 2. Distraksiyon sonrası oluşan çapraz kapanış.

\section{İstatistiksel Değerlendirme: KMY} yoğunluğu ölçümlerinden elde edilen sonuçlar 'Tek örneklem $\mathrm{T}$ Testi ile değerlendirilmiş ve her grubun ortalama ve standart sapma değerleri ve aralarındaki anlamlılıkları analiz edilmiştir.

\section{BULGULAR}

Kemik mineral yoğunluğunun ölçümü klinik olarak kemiğin kuvveti ve yük taşıma kapasitesi ile ilişkili olarak bilgi verir. KMY' nun yüksek olduğu değerlerde düşük olduğu değerlere oranla ölçüm yapılan kemiğin mineral yoğunluğunun yüksek olduğu ve daha fazla yük taşıyabileceği ortaya konulmuş olur. Çalışmamızda elde ettiğimiz KMY değerlerine bakıldığında, kontrol grubunda operasyon sonrası 30' uncu günde değerlerin azaldığı görülmüştür (Tablo 1). 60' 1nc1 günde tavşanların bir tanesi başlangıç seviyesinin üzerinde bir değere ulaşmış, bir tavşan başlangıç seviyesinde kalmış, diğer iki tavşan başlangıç seviyesinin altında bir KMY değerleri göstermiştir. Ortalama KMY değerleri incelendiğinde gerek 30'uncu gün gerekse 60' incı gün değerlerinin başlangıç değerlerinin altında olduğu görülmüştür (Tablo 2). Bu fark 30' uncu günde daha belirgin olarak bulundu. Kontrol grubundaki tavşanların ortalama KMY değerlerinin zamana göre birbirleriyle ikili karşılaştırmaları istatistiksel olarak anlamlı bulunmuştur $(p<0,05)$.

Tablo 1. Kontrol grubu KMY değerleri.

\begin{tabular}{|l|c|c|c|}
\hline Kontrol Grubu & Başlangıç & 30'uncu Gün & 60'ıncı Gün \\
\hline Tavşan 5 & 0.400 & 0.286 & 0.321 \\
\hline Tavşanı 6 & 0.356 & 0.261 & 0.341 \\
\hline Tavşan 7 & 0.354 & 0.247 & 0.357 \\
\hline Tavşan 8 & 0.324 & 0.279 & 0.357 \\
\hline Ortalama & $\mathbf{0 . 3 7 4}$ & $\mathbf{0 . 2 6 8}$ & $\mathbf{0 . 3 4 4}$ \\
\hline Std. Sapma & $\mathbf{0 . 0 5 9}$ & $\mathbf{0 . 0 1 8}$ & $\mathbf{0 . 0 1 7}$ \\
\hline
\end{tabular}


Tablo 2. Kontrol grubu KMY ortalamaları.

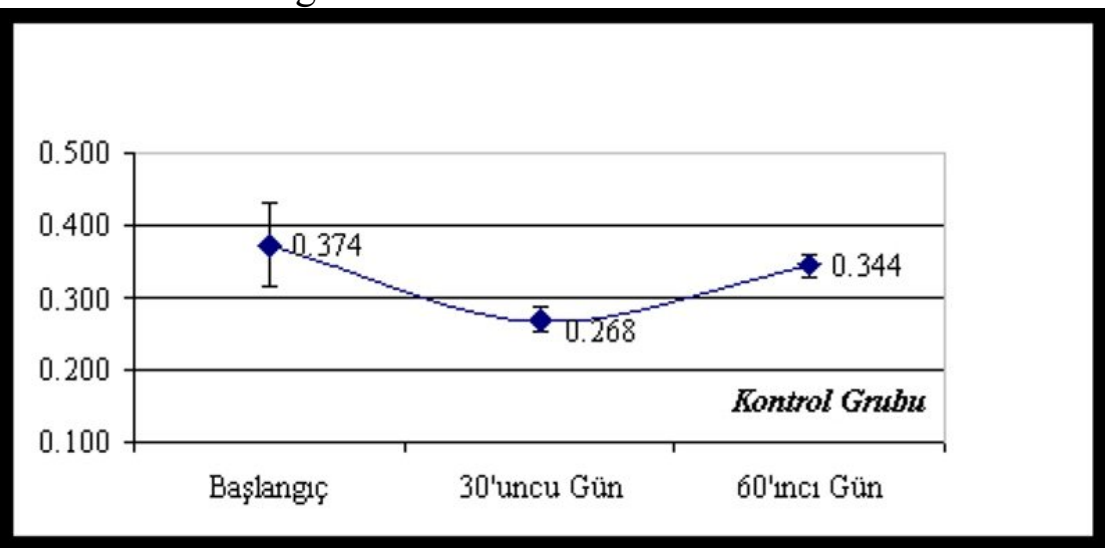

DYUS uygulanan grupta KMY değerlerinin hem 30 hem de 60'1nc1 günlerde başlangıç seviyesinin üstünde olduğu gözlenmiştir (Tablo 3). Bu grupta tavşanlarda KMY' nun 30' uncu günde elde edilen ortalama değerinin operasyon öncesi seviyeden daha yüksek bir değerde olduğu, 60'1nc1 gün sonunda ise 30' uncu gün sonuçlarına göre bir miktar daha arttığ 1 görülmektedir (Tablo 4). DYUS grubunda 30 ve $60^{\prime}$ incı günlerde ölçülen $\mathrm{KMY}$ değerlerinin ikili olarak birbirleriyle karşılaştırmalarında veriler istatistiksel olarak anlamlı bulunmuştur $(p<0.05)$.

Tablo 3. DYUS grubu KMY değerleri.

\begin{tabular}{|l|c|c|c|}
\hline DYUS Grubu & Başlangıç & 30'uncu Gün $^{\prime}$ & 60'ıncı Gün \\
\hline Tavşan 1 & 0.326 & 0.331 & 0.329 \\
\hline Tavşan 2 & 0.336 & 0.373 & 0.378 \\
\hline Tavşan 3 & 0.341 & 0.391 & 0.387 \\
\hline Tavşan 4 & 0.364 & 0.379 & 0.393 \\
\hline Ortalama & $\mathbf{0 . 3 4 2}$ & $\mathbf{0 . 3 6 9}$ & $\mathbf{0 . 3 7 2}$ \\
\hline Std. Sapma & $\mathbf{0 . 0 1 6}$ & $\mathbf{0 . 0 2 6}$ & $\mathbf{0 . 0 2 9}$ \\
\hline
\end{tabular}

Tablo 4. DYUS grubu KMY ortalamaları.

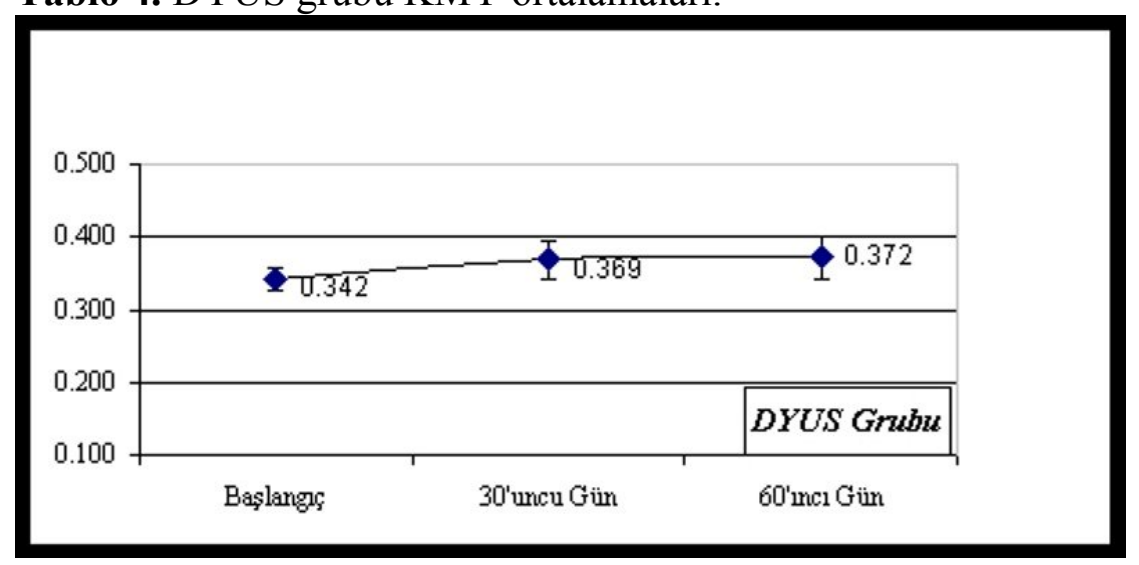




\section{TARTIŞMA}

Ortopedi alanında geniş bir kullanım alanına sahip olan distraksiyon osteogenezi, son 20 yil içerisinde maksillofasiyal cerrahide konjenital ve kazanılmış birçok deformitenin ve kemik kaybının düzeltilmesi amaciyla uygulanmaya başlanmıştır. DO, kemik greftleme işlemlerine ihtiyaç duymadan ve bu sayede ikinci bir cerrahi saha oluşturmadan, hasta üzerinde operasyon stresini azaltarak kemik kazanılmasına olanak tanır. $\mathrm{Bu}$ önemli avantajın yanında histogenezis ile yumuşak doku kazanılmasını sağlar. İkinci cerrahi işlem gerektirmesi ve distraktörün tedavi süresince bölgede tutulma gerekliliği DO'nin dezavantajları olarak sayılabilir.

DO ile ilgili literatürde yer alan çalışmalarda farklı hayvan modelleri tanımlanmıştır. Köpek, ${ }^{8,9,10}$ koyun ${ }^{11,12,13}$, domuz $^{14,15}, \operatorname{tavşan}^{16,17}$ ve rat $^{18,19}$ ile’ yapılmış birçok çalışma vardır. Büyük boyutlardaki hayvan modellerinin kullanımı çalışma kolaylığı ve mandibula boyutlarının insana benzerliği yönünden avantaj görülmekle beraber, istatistiksel olarak anlam ifade edecek sayıda hayvan kullanımı, beraberinde bakım ve muhafaza gibi zorluklar getireceğinden araştırmalarda daha çok tavşan, rat gibi deney hayvanları tercih edilmektedir. $\mathrm{Bu}$ çalışmada tavşan tercih edilmesinin nedeni hem tavşan mandibulasının insan mandibulasına yapısal olarak benzerliği ve uygulama kolaylığı, hem de daha ucuz, bakımı kolay, etik açıdan daha kabul edilebilir ve denenmiş bir model olmasıdır.

DO' inde başarı, latent süre, distraksiyon hızı ve ritmi, konsolidasyon süresi gibi birçok parametreyle ilişkilidir. Latent ve konsolidasyon periyotlarının kısa olması, olası enfeksiyon ve başarısızlık risklerini en aza indirir. $\mathrm{Bu}$ amaç doğrultusunda literatürde kemik rejenerasyonunu hızlandırarak tedavi süresini kısaltmak amacıyla pek çok yöntem yer almaktadır.

DO' inde latent periyot ile ilgili çalışmalarda birçok farklı varyasyon uygulanmıştır. Ilizarov 1989 yılında yaptığı çalışmada latent periyodun erişkinlerde 7 gün olması gerektiğini, çocuklarda ise bu sürenin daha kısa olabileceğini bildirmiştir. ${ }^{1}$ Aida ve ark. ${ }^{20}$ 2003 yılında DO uyguladıkları tavşan mandibulasinda $0,2,5$ ve 10 günlük latent periyodu karşılaştırmışlardır. 0 ve 2 gün beklenen grupta kemik trabekülü oluşmadığını, 5 gün beklenen grupta ise distraksiyon aralığının olgunlaşmamış kemik trabekülü yönünden zengin olduğunu, sonuç olarak tavşan mandibula distraksiyonunda en uygun latent sürenin 5 gün olduğunu belirtmişlerdir. Tüz ve arkadaşları $^{21,22}$ DO uygulanan tavşanlarda 1-6 aylık süre içerisinde masseter kasın histomorfometrik değişimini araştırdıkları iki ayrı çalışmada latent süre olarak 5 gün beklenmesinin yeni kemik dokunun fiziksel dayanıklılığı açısından en iyi sonucu vereceğini bildirmişlerdir. Birçok araştırmacı uzun kemiklerde yapılmış olan çalışmaların sonuçlarından yola çıkarak DO' inde 7 güne kadar latent süre uygulamasını uygun bulmaktadır. Mevcut çalışmada ilgili literatür bilgileri ve çalışmamızda kullanılan tavşanların ağırlık, boy ve mandibula boyutları göz önüne alınarak latent periyodun 7 gün olarak uygulanması uygun görülmüştür.

DO uygulamalarının avantajlarının yanı sıra önemli dezavantajlarından biri konsolidasyon süresinin uzun olmasıdır. $\mathrm{Bu}$ süre ile ilgili çalışmaların bazılarında santimetre başına ortalama kemiklessme zamanı 28-36 gün olarak bildirilmiştir. ${ }^{23,24}$ El-Bialy ve ark. $^{25}$ distraksiyona uğramış tavşan mandibulasında 4 haftalık konsolidasyon süresi sonunda kallusun daha olgunlaşmış olduğu ve olgun lameller kemik içerdiğini bildirmişlerdir. Bununla beraber konsolidasyon periyodunun santimetre başına 1-2 ay süre olmasının uygun bir süreç olduğu belirtmişlerdir. Daha önce aynı tür üzerinde yapılmış olan DO uygulamaları ile ilgili çalışmalardan yola çıkarak çalışmamızda konsolidasyon periyodu 60 hafta olarak belirlenmiştir. Ancak KMY değerlendirmeleri hem 30 
hem de 60'ıncı gün sonunda yapılarak sonuçların karşılaştırmalı olarak değerlendirilmesi amaçlanmıştır.

Düşük yoğunlukta ultrason uygulamalarının kırık iyileşmesini hızlandırdığ 1 deneysel ve klinik çalışmalarda gösterilmiştir. Duarte ${ }^{26} 1983$ yılında düşük yoğunlukta ultrason uygulamasının kemik iyileşmesi üzerine olumlu etkilerini bildirmiştir. $\mathrm{Bu}$ çalışmanın ardından DYUS' nun uzun kemiklerin kırıklarının tedavisinde hızlandırıc1 etkisi olduğunu bildiren çalışmalar yayınlanmıştır. ${ }^{27,28}$ Fedotov ve ark. $^{29} 1986$ yılında tavşanlarda mandibula kırıklarının tedavisinde, Harris ve arkadaşlarının $^{30} 1992$ yılında mandibulada osteoradyonekroz tedavisi amaciyla ultrason kullanmalarının ardından, maksillofasiyal cerrahide terapötik olarak ultrason uygulamaları yer almaya ve araştırıcıların ilgisini çekmeye başlamıştır.

DYUS uygulamasinın dokular ve hücreler üzerinde 1s1 artışı ve enerji emilimi ile değişiklik yarattığ bildirilmiştir. $\quad 20-50 \quad \mathrm{~mW} / \mathrm{cm} 2$ yoğunluğundaki ultrason uygulamasının dokuda 1S1 artışı olarak $1{ }^{\circ} \mathrm{C}$ ' den az etkisi olduğu belirtilmiştir. ${ }^{31}$ Dokudaki bu minimal 1Sı artışına rağmen matriks metolloproteinaz 1 (kollajenaz 1) gibi enzimlerin miktarında değişiklikler meydana getirdiği gösterilmiştir. ${ }^{32}$ Fyfe ve ark. $^{33}$ ratlarda ultrasonun mast hücrelerinin salgılanmasını uyararak ödemi azalttığını bildirmişlerdir. Maxwell ${ }^{34} \quad$ kırık iyileşmesinde enflamasyon periyodunda, ultrason stimülasyonunun endotele lökosit adezyonun arttırdığını bildirirken, Doan ${ }^{25}$ ve $\operatorname{Reher}^{36}$ fibroblastlardan kollajen sentezini uyardığını ve makrofaj, fibroblast, vasküler endotelyal büyüme faktörü salgılanmasını provoke ettiğini rapor etmişlerdir.

In vitro olarak yapılmış olan çalışmalarda, ultrason tedavisinin osteojenik hücreler üzerinde mekanik stres oluşturarak proliferasyonu ve osteoblastik aktiviteyi uyardığı gösterilmiştir. $28,35,37,38$
Dyson ve Brookes ${ }^{39}$ sıçanlar üzerinden uyguladıkları $500 \mathrm{~mW} / \mathrm{cm} 2$ 'lik ultrason stimülasyonu ile bilateral fibular fraktürlerini incelemişler; ultrasonun özellikle fraktürün erken safhalarında etkili olduğu bulgusuna ulaşmışlardır. Ding ve ark. $^{40} 2009$ y1lında köpekler üzerinde yaptıkları bir çalışmada, distraksiyon periyodu sırasında günde 20 dakika süre ile $40 \mathrm{~mW} / \mathrm{cm}^{2}$ DYUS uyguladıklarını ve KMY ölçümlerinde kontrol grubuna göre $2,4,6,8$ ve 12 'inci haftalarda daha yüksek değerlere ulaştıklarını bildirmişlerdir.

Tamir periyodunda oluşan kallus kondrogenez ve osteogenez ile meydana gelmektedir ve ultrasonun her iki işlemi de direk olarak uyardığı literatürde yer almaktadir. Kondrogenez esnasinda ultrason stimülasyonunun kondrosit proliferasyonunu uyardığı bildirilirken. ${ }^{41,42}$ kondrosit içerisindeki kalsiyum konsantrasyonunu da $\operatorname{arttırdığ1~rapor~}$ edilmiştir. $^{43}$ Çalışmamızda literatür bilgileri 1şığında DYUS uygulamasının erken kemikleşme döneminde kemik mineral yoğunluğunu ve sertliğini daha hızlı şekilde arttırabileceğini düşünerek uygulamanın distraksiyon periyodunda yapılması planlanmıştır.

Yang ve ark. ${ }^{44}$ ratlar üzerinde yapmış olduğu çalışmalarında, 50 ve $100 \mathrm{~mW} / \mathrm{cm} 2$ yoğunluktaki ultrason stimülasyonu uygulamasının etkinliğini karşılaştırmış ve $50 \mathrm{~mW} / \mathrm{cm} 2$ yoğunluğunda ultrason stimülasyonu uygulanan grupta yeni oluşan kemiğin mekanik özelliklerinin $100 \mathrm{~mW} / \mathrm{cm} 2$ grup ile tedavi edilmeyen gruba göre daha iyi olduğunu bildirmişlerdir. Harle ve ark. ${ }^{45}$ hücrelerin ultrason stimülasyonuna verdikleri yanıtın özellikle yoğunlukla ilişkili olduğunu bildirmiştir. Çalışmalarında 120,390 ve $1490 \mathrm{~mW} / \mathrm{cm} 2$ yoğunluklarında ultrason stimülasyonu uygulamış ve yoğunluğun artmasiyla beraber alkalen fosfataz miktarının da arttığını bildirmiştir. $^{45}$ Çalışmamızda benzer hayvan modelinde düşük yoğunluktaki ultrason uygulamalarının $\quad 20-100 \quad \mathrm{~mW} / \mathrm{cm} 2$ aralığında değiştiği ve uygun tedavi edici 
dozun ise $30-50 \mathrm{~mW} / \mathrm{cm} 2$ ve $1-1.5 \mathrm{Mhz}$ aralığında olduğunu ${ }^{26,40,46}$ göz önüne alarak $30 \mathrm{~mW} / \mathrm{cm} 2 \quad(1 \mathrm{Mhz})$ yoğunlukta ultrason stimülasyonu uygulaması tercih edilmiştir.

KMY ölçümünde kantitatif tomografi ve DEXA en uygun ölçüm yöntemi olarak rapor edilmiştir. ${ }^{47}$ Bilgisayarlı kantitatif tomografide mevcut tüm kemik yap1 3 boyutlu olarak incelenebilmekle beraber yüksek doz radyasyon içermesi ve pahalı bir yöntem olması dezavantajdır. DEXA'nın avantajı düşük dozda radyasyon içermesi, bunun yanında yüksek çözünürlükte görüntü vermesi ile gerçeğe yakın bir tahmin yapılabilmesine yardımc1 olmasıdır. DEXA, kemik mineral yoğunluğunun ölçümünde güvenli ve geçerli bir yöntemdir ve kemik dokunun biyomekanik karakteri ile görüntüleme arasında iyi bir bağıntı vardır. DEXA boyutlu ölçüm yaptığından dolayı $X$ 1şınının üst üste gelen bölgelerde ölçüm aşamasında yetersiz kalabilmektedir.

Çalışmamızda kontrol grubunda yapmış olduğumuz 30 ve 60'ınc1 gün ölçümlerinde, DYUS uygulanmamış distraksiyon sahasında 30 gün sonunda KMY' nun düştüğü gözlenmiştir. $\mathrm{Bu}$ grupta 60 gün sonunda başlangıca yakın KMY yoğunluğu değerleri elde edilmiştir. DYUS uygulanan grupta KMY değerlerinin hem 30 hem de 60' inc1 günlerde başlangıç seviyesinin üstünde olduğu gözlenmiştir. 60' 1nc1 gün sonuçları ile 30' uncu gün sonuçları karşılaştırıldığında DYUS grubunda 60' 1ncı günde oluşan KMY artışının ilk periyotta oluşana oranla daha az olduğu; bölgedeki iyileşmenin önemli kısmının ilk bir aylık süreçte tamamlandığ 1 gözlenmiştir. $\mathrm{Bu}$ durumda DYUS' un etkisiyle kemik olgunlaşmasının büyük bir bölümünün ilk 30 günde tamamlandığı ve kazanılan kemiğin fonksiyonel kuvvetlere direnç gösterebileceği düşünülebilir.

\section{SONUÇ}

Çalışmamız küçük bir grubu içerse de elde edilen sonuçlar ışığında DYUS' un klinik olarak fayda sağlayabileceği, kırık tedavilerinde fiksasyonun daha erken sonlandırılmasını ya da minör cerrahi işlemlerde postoperatif ödemin azaltılmasını ve iyileşmenin hızlandırılmasını sağlayabileceği ön görülebilir. Bunlara ek olarak kemik içi implantlarin osteointegrasyonun hızlandırılmasında ve temporomandibular düzensizliklerin tedavisinde de fayda sağlayabilir. İnvaziv bir yöntem olmaması nedeni ile klinik uygulamalarının yapılmasın1, distraksiyon periyodunun yanı sira konsolidasyon periyodunda da uygulanarak karşılaştırmalı olarak araştırılması gerektiğini düşünmekteyiz.

\section{KAYNAKLAR}

1. Ilizarov GA. The tension-stress effect on the genesis and growth of the tissues Part 1; The influence of stability of fixation and soft tissue preservation. Clin Orthop 1989;238:249-281.

2. Lynch SE, Genco RJ, Marx RE. Tissue Engineering Apllications in Maxillofacial Surgery and Periodontics. Quintessence Publisihing Co Inc, Chicago, 1999;131-146.

3. Codivilla A. On the means of lengthening, in the lower limb the muscles and tissues which are shortened through deformity. Am J Orthop Surg 1905;2:353-369.

4. Snyder CC, Levine GA, Swanson HM. Mandibular lengthening by gradual distraction. Preliminary report. Plast Reconstr Surg 1973;51:505-514.

5. Mccarthy JG, Schreiber J, Karp N, Thorne CH, Grayson BH. Lengthening the human mandible by gradual distraction. Plast Reconstr Surg 1992;89(1):1-8. [CrossRef]

6. Ryaby JT. Clinical effects of electromagnetic and electric fields on fracture healing. Clin Orthop 1998;355:205-215. [CrossRef]

7. Hadjiargyrou M, Mcleod K, Ryaby JP, Rubin C. Enhancement of fracture 
healing by low intensity ultrasound. Clin Orthop 1998;355S:216-229. [CrossRef]

8. Ganey TM, Klotch DW, Sasse J. Basement membrane of blood vessels during distraction osteogenesis. Clin Orthop 1994;301:132-139. [CrossRef]

9. Klotch DW, Ganey TM, Slater-Haase A. Assessment of bone formation during osteoneogenesis: A canine model. Otolaryngol Head Neck Surg 1995;112:291-302. [CrossRef]

10. Cope JB, Samchukov ML. Mineralization dynamics of regenerate bone during mandibular osteodistraction. Int J Oral Maxillofac Surg 2001;30:234-242. [CrossRef]

11. Karaharju-Suvanto T, Karaharju EO, Ranta R. Mandibular distraction. An experimental study on sheep. J Craniomaxillofac Surg 1990;18:280283.

12. Tavakoli $\mathrm{K}$, Walsh WW, Bonar F. The role of latency in mandibular osteodistraction. J Craniomaxillofac Surg 1998;26:209-219. [CrossRef]

13. Ayoub AF, Richardson W, Koppel D. Segmental mandibular reconstruction by microincremental automatic distraction osteogenesis: An animal study. Br J Oral Maxillofac Surg 2001;39:356-364.

14. Troulis MJ, Glowacki J, Perrott DH. Effects of latency and rate on bone formation in a porcine mandibular distraction model. J Oral Maxillofac Surg 2000;58:507-513. [CrossRef]

15. Wiltfang J, Kessler $P$, Merten HA. Continuous and intermittent bone distraction using a microhydraulic cylinder: An experimental study in minipigs. Br J Oral Maxillofac Surg 2001; 39:2-7. [CrossRef]

16. Califano L, Cortese A, Zupi A. Mandibular lengthening by external distraction: An experimental study in the rabbit. J Oral Maxillofac Surg 1994;52:1179-1183. [CrossRef]

17. Al Ruhaimi KA. Comparison of different distraction rates in the mandible: An experimental investigation. Int $\mathrm{J}$ Oral Maxillofac Surg 2001;30:220-227. [CrossRef]

18. Rowe NM, Mehrara BJ, Dudziak ME. Rat mandibular distraction osteogenesis: Part I. Histologic and radiographic analysis. Plast Reconstr Surg 1998;102:2022-2032. [CrossRef]

19. Warren SM, Mehrara BJ, Steinbrech DS. Rat mandibular distraction osteogenesis: Part III. Gradual distraction versus acute lengthening. Plast Reconstr Surg 2001;107:441453. [CrossRef]

20. Aida T, Yoshioka I, Tominaga K, Fukuda J. Effects of latency period in a rabbit mandibular distraction osteogenesis. Int $\mathrm{J}$ Oral Maxillofac Surg 2003;32(1):54-63. [CrossRef]

21. Tüz HH, Kişnişci RŞ, Günhan Ö. Histomorphometric evaluation of short-term changes in masseter muscle after lengthening the rabbit mandible by distraction osteogenesis. J Oral Maxillofac Surg 2003;61:615-620. [CrossRef]

22. Tüz HH, Dolanmaz A,bPampu AA, Kişnişci RŞ, Günhan Ö. Histomorphometric evaluation of delayed changes in masseter muscle after lengthening the rabbit mandible by distraction osteogenesis. Oral Diseases 2009; 15:142-147.

23. Fischgrund J, Paley D, Suter C. Variables affecting time to bone healing during limb lengthening. Clin Orthop 1994;301:31-38. [CrossRef]

24. Aldegheri R. Femoral callotasis. J Pediatr Orthop: Part B 1997;6:42-49. [CrossRef]

25. El-Bialy TH, Royston TJ, Magin RL. The effect of pulsed ultrasound on mandibular distraction. Ann Biomed Eng 2002;30:1251-1261. [CrossRef]

26. Duarte LR. The stimulation of bone growth by ultrasound. Arch Orthop Trauma Surg 1983;101:153-162. [CrossRef]

27. Rubin C, Bolander M, Ryaby JP. The use of low-intensity ultrasound to 
accelerate the healing of fractures. $\mathrm{J}$ Bone Joint Surg Am 2001;83.259-265

28. Warden SJ, Favaloro JM, Bennell KL. Low-intensity pulsed ultrasound stimulates a bone-forming response in UMR-106 cells. Biochem Biophys Res Comm 2001;286:443-450. [CrossRef]

29. Fëdotov SN, Minin EA, Borisov IN. Effect of local cooling and ultrasound on the reparative processes following mandibular fracture. Stomatologiia (Mosk);1986;65:4-6.

30. Harris M. The conservative management of osteoradionecrosis of the mandible with ultrasound therapy. Br J Oral Maxillofac Surg 1992;30: 313-318. [CrossRef]

31. Chang WH, Sun JS, Chang SP, Lin JC. Study of thermal effects of ultrasound stimulation on fracture healing. Bioelectromagnetics 2002;23(4):256-263. [CrossRef]

32. Welgus HG, Jeffrey JJ, Eisen, AA, Roswit WT, Stricklin GP. Human skin fibroblast collagenase: interaction with substrate and inhibitor. Coll Relat Res 1985;5(2):167-179.

33. Fyfe MC, Chahl LA. The effect of ultrasound on experimental oedema in rats. Ultrasound Med Biol 1980;6(2):107-111. [CrossRef]

34. Maxwell L, Collecutt $T$, Gledhill $M$, Sharma S, Edgar S, Gavin JB. The augmentation of leucocyte adhesion to endothelium by therapeutic ultrasound. Ultrasound Med Biol 1994;20:383-390. [CrossRef]

35. Doan N, Reher P, Meghji S, Harris M. In vitro effects of therapeutic ultrasound on cell proliferation, protein synthesis, and cytokine production by human fibroblasts, osteoblasts, and monocytes. J Oral Maxillofac Surg 1999;57:409-419. [CrossRef]

36. Reher P, Doan N, Bradnock B, Meghji $S$, Harris M. Effect of ultrasound on the production of IL-8, basic FGF and
VEGF. Cytokine 1999;11:416-423. [CrossRef]

37. Sun JS, Tsuang YH, Lin FH. Bone defect healing enhanced by ultrasound stimulation: an in vitro tissue culture model. J Biomed Mater Res 1999;46:253-261. [CrossRef]

38. Sun JS, Hong RC, Chang WH. In vitro effects of low-intensity ultrasound stimulation on the bone cells. J Biomed Mater Res 2001;57:449-456. [CrossRef]

39. Dyson M, Brookes M. Stimulation of bone repair by ultrasound. Ultrasound Med Biol Suppl 1983;2:61-67.

40. Ding $Y$, Li G, Zhang $X$, Jianhua AO, Liu W, Qin MA, Liu Y, Liu B. Effect of low-intensity pulsed ultrasound on bone formation during mandible distraction osteogenesis in a canine model. a preliminary study. J Oral Maxillofac Surg 2009;67:2431-2439.

41. Wiltink A, Nijweide PJ, Oosterbaan WA, Hekkenberg RT, Helders PJM. Effect of therapeutic ultrasound on endochondral ossification. Ultrasound Med Biol 1995;21:121-127. [CrossRef]

42. Wu CC, Lewallen DG, Bolander ME, Bronk J, Kinnick R, Greenleaf JF. Exposure to low intensity ultrasound stimulates aggrecan gene expression by cultured chondrocytes. Trans Orthop Res Soc 1996;21:622-634.

43. Parvizi J, Parpura V, Kinnick RR, Greenleaf JF, Bolander ME. Low intensity ultrasound increases intracellular concentrations of calcium in chondrocytes. Trans Orthop Res Soc 1997;22:465-470.

44. Yang KH, Parvizi J, Wang SJ, Lewallen DG, Kinnick RR, Greenleaf $\mathrm{JF}$, Bolander ME. Exposure to lowintensity ultrasound increases aggrecan gene expression in a rat femur fracture model. Journal of Orthopaedic Research 1996;14(5):802-809. [CrossRef]

45. Harle J, Salih V, Knowles JC, Mayia F, Olsen I. Effects of therapeutic 
ultrasound on osteoblast gene expression. J Mater Sci 12(1012):1001-1004.

46. Tis JE, Meffert $\mathrm{CR}$, Inoue $\mathrm{N}$, Mccarthy EF, Machen MS, Mchale KA, Chao EYS. The effect of low intensity pulsed ultrasound applied to rabbit tibiae during the consolidation phase of distraction osteogenesis. J
Orthop Res 2006;20:793-800. [CrossRef]

47. Eyres KS, Bell MJ, Kanis JA. Methods of assessing new bone formation during limb lengthening. Ultrasonography, dual energy x-ray absorptiometry and radiography compared. J Bone Joint Surg 1993;75B:358-364. 